\title{
Profiles of Practice in the Public Junior College Library
}

\begin{abstract}
In an effort to delineate an experimental set of quantitative standards for evaluating junior college library service, the authors ranged management data from eighty-six selected junior college libraries on a graded percentile chart. They then plotted the experience of seven "benchmark" institutions on the chart in order to portray their characteristics graphically and comparably. It is their intention to continue developing data on these seven institutions in hope of generating quantitative norms that can be used for evaluative purposes.
\end{abstract}

$I_{1}$ T is Difficult to formulate specific qualitative criteria by which the adequacy of a public junior college library can be measured. Not quite as difficult, however, is the measuring of quantitative supportive characteristics which form the necessary basis for quality service. It is possible for example, to compare the management data of different libraries with each other, provided the institutions they serve are similar. What is more, it is possible to portray this supportive data graphically so that a given library can see how it compares with certain benchmarks or how it compares with other libraries serving similar institutions.

Henry Ford Community College wanted to make a comparison of its supportive library characteristics with the characteristics of other libraries serving similar colleges. The study that emerged ranges management data taken from $\mathrm{Li}$ brary Statistics of Colleges and Universities, 1963-64 in percentile rank, suggests benchmarks which change with the years; and demonstrates a technique

Mr. Tanis is Director of the Library at Kansas State College, Pittsburg, and Mr. Powers is Head of Institutional Research at Henry Ford Community College, Dearborn, Michigan. whereby libraries can graphically compare each other's supportive characteristics such as number of volumes, number of periodicals, number of professional personnel, expenditures per FTE student, and number of square feet of assignable space in the library. ${ }^{1}$

This study finally emerges with the profiles of practice in six libraries. The data of these libraries becomes, in effect, six hypotheses illustrating what the supportive characteristics of a public junior college library ought to be.

The following criteria were used to select the junior colleges to be studied from all the libraries in Library Statistics:

1. Only public institutions were chosen.

2. Only two-year institutions were chosen.

3. Only institutions which had been established for at least seven years or more were included.

4. Only institutions with 1,000 full-time (FTE) students or more were selected.

5. Only accredited institutions were included.

${ }^{1}$ U.S. Office of Education. Library Statistics of Colleges and Universities, 1963-64. Institutional Data. Washington: 1965. Student and faculty data supplemented by American Association of Junior Colleges, Junior College Directory, 1965. Washington: 1965. 
TABLE 1

\begin{tabular}{|c|c|c|c|c|c|c|c|c|c|c|c|c|c|}
\hline & $\begin{array}{c}\text { Per- } \\
\text { centile }\end{array}$ & $\begin{array}{l}\text { F.T.E. } \\
\text { Students }\end{array}$ & $\begin{array}{l}\text { F.T.E. } \\
\text { Faculty }\end{array}$ & $\begin{array}{l}\text { Total } \\
\text { Vols. }\end{array}$ & $\begin{array}{l}\text { Vols. } \\
\text { Added }\end{array}$ & $\begin{array}{l}\text { Vols. } \\
\text { With- } \\
\text { drawn }\end{array}$ & $\begin{array}{c}\text { Per. } \\
\text { being } \\
\text { rec'd }\end{array}$ & $\begin{array}{l}\text { Hrs. of } \\
\text { Stud. Asst. }\end{array}$ & $\begin{array}{l}\text { F.T.E. } \\
\text { Prof. } \\
\text { Pers. }\end{array}$ & $\begin{array}{l}\text { F.T.E. } \\
\text { Non- } \\
\text { Prof. } \\
\text { Pers. }\end{array}$ & $\begin{array}{c}\text { Total } \\
\text { Expenditure }\end{array}$ & Salaries & Wages \\
\hline & 99 & 9,219 & 335 & 71,109 & 8,167 & 1,880 & 736 & 100,000 & 8.0 & 9.5 & $\$ 202,267$ & $\$ 101,361$ & $\$ 18,000$ \\
\hline & 90 & 6,668 & 279 & 42,294 & 5,036 & 830 & 465 & 6,552 & 5.0 & 6.9 & 104,241 & 71,426 & 7,213 \\
\hline & 80 & 4,696 & 226 & 33,976 & 4,537 & 621 & 382 & 4,376 & 4.0 & 4.5 & 99,211 & 54,846 & 5,663 \\
\hline & 75 & 4,535 & 210 & 32,285 & 4,132 & 576 & 372 & 4,197 & 4.0 & 4.3 & 86,097 & 46,488 & 5,120 \\
\hline \multirow{3}{*}{ 75th Percentile } & 70 & 4,133 & 193 & 27,800 & 3,925 & 465 & 350 & 3,800 & 3.5 & 4.0 & 70,809 & 40,672 & 4,501 \\
\hline & 60 & 3,031 & 145 & 25,306 & 3,208 & 350 & 315 & 3,316 & 3.0 & 3.0 & 61,325 & 37,565 & 3,600 \\
\hline & 50 & 2,393 & 125 & 22,500 & 2,437 & 250 & 287 & 2,668 & 3.0 & 3.0 & 55,200 & 34,819 & 3,262 \\
\hline \multirow{6}{*}{ Median } & 40 & 2,098 & 106 & 20,736 & 2,120 & 160 & 258 & 2,156 & 2.5 & 2.2 & 46,998 & 30,142 & 2,520 \\
\hline & 30 & 1,891 & 96 & 17,000 & 1,879 & 111 & 230 & 1,596 & 2.0 & 2.0 & 41,307 & 24,010 & 1,892 \\
\hline & 25 & 1,772 & 90 & 15,946 & 1,800 & 100 & 215 & 1,450 & 2.0 & 2.0 & 37,825 & 20,600 & 1,581 \\
\hline & 20 & 1,717 & 85 & 15,084 & 1,679 & 75 & 200 & 1,240 & 2.0 & 1.5 & 33,050 & 18,200 & 1,400 \\
\hline & 10 & 1,441 & 66 & 13,038 & 1,355 & 40 & 164 & 600 & 1.0 & 1.0 & 24,229 & 13,255 & 700 \\
\hline & 1 & 1,092 & 51 & 8,877 & 600 & 1 & 45 & 196 & 1.0 & 1.0 & 16,423 & 7,647 & 225 \\
\hline
\end{tabular}

TABLE 2



\begin{tabular}{|c|c|c|c|c|c|c|c|c|c|c|c|c|c|}
\hline 99 & $\$ 61,472$ & $\$ 3,500$ & $\$ 14,800$ & 78 & 80,000 & 23,762 & 30,000 & 10,000 & 20,000 & $\$ 124$ & $\$ 1,322$ & 9.1 \\
\hline
\end{tabular}

\begin{tabular}{|l|l|l|l|l|l|l|r|r|r|r|r|r|}
\hline 90 & 36,300 & 2,290 & 7,587 & 68 & 32,750 & 16,236 & 14,750 & 5,474 & 8,415 & 45 & 904 & 5.3 \\
\hline
\end{tabular}

\begin{tabular}{l|l|l|l|l|l|l|r|r|r|r|r|r|r|r|}
\hline 80 & 24,225 & 1,323 & 5,299 & 68 & 21,900 & 5,166 & 9,856 & 2,720 & 5,356 & 28 \\
\hline
\end{tabular}

\begin{tabular}{ll|l|l|l|l|l|l|l|l|l|l|l|l|l|}
\hline 75 th Percentile & 75 & 22,472 & 1,231 & 4,678 & 66 & 20,400 & 4,800 & 9,000 & 2,320 & 5,119 & 26 & 703 & 4.2 \\
\hline 70 & 21,224 & 1,144 & 4,135 & 66 & 18,850 & 4,500 & 8,219 & 2,250 & 4,610 & 24 & 652 & 4.1
\end{tabular}

\begin{tabular}{l|l|l|l|l|l|l|l|l|l|l|l|l|l|l|}
70 & 21,224 & 1,144 & 4,135 & 66 & 18,850 & 4,500 & 8,219 & 2,250 & 4,610 & 24 \\
\hline 60 & 17,970 & 1,012 & 2,900 & 65 & 15,500 & 4,000 & 7,000 & 1,688 & 2,563 & 22 & 598 \\
\hline 50 & 14,453 & 813 & 1,941 & 64 & 13,084 & 2,500 & 6,350 & 1,413 & 2,300 & 19 & 549 & 3.7 \\
\hline
\end{tabular}

Median

\begin{tabular}{|c|c|c|c|c|c|c|c|c|c|c|c|c|}
\hline 40 & 12,688 & 575 & 1,514 & 62 & 11,000 & 2,165 & 4,800 & 1,200 & 1,840 & 18 & 481 & 3.4 \\
\hline 30 & 11,500 & 464 & 1,008 & 59 & 8,944 & 1,728 & 3,280 & 816 & 1,444 & 16 & 465 & 3.0 \\
\hline 25 & 10,000 & 354 & 903 & 58 & 6,912 & 1,555 & 2,888 & 679 & 1,300 & 15 & 446 & 2.8 \\
\hline 20 & 9,300 & 293 & 790 & 57 & 5,300 & 1,398 & 2,610 & 528 & 900 & 14 & 417 & 2.6 \\
\hline 10 & 6,350 & 225 & 500 & 52 & 3,409 & 960 & 1,840 & 304 & 500 & 12 & 235 & 2.3 \\
\hline 1 & 4,823 & 100 & 255 & 40 & 1,900 & 237 & 900 & 149 & 100 & 5 & 12 & 1.6 \\
\hline
\end{tabular}


6. Only institutions listed in Colleges and Universities, 1963-64 were used. The application of these criteria resulted in the selection of eighty-six institutions from a total population of 281 public junior college libraries.

All of the raw management data for the eighty-six libraries in this study were converted to percentile ranking. The management categories were ranged across the top of the chart. Percentile gradations were ranged along the left hand column.

From this comprehensive chart, the final graphic presentation was derived. Each management data item which fell on the 1st, 10th, 20th, 25th, 30th and on through the 99th percentile was recorded. The final result is portrayed in Tables 1 and 2.

It is a simple matter to draw a line at the 50th percentile to obtain median benchmarks for institutions in this study.

\section{Median BENCHMARKS For 1963-64}

Number of volumes at the end of year

22,500

Number of volumes added during the year

Number of volumes withdrawn during year .

Number of periodicals being received at end of year .

Number of hours of student assistance

Number of professional personnel (FTE)

Number of nonprofessional personnel (FTE)

Total library expenditures (excluding capital outlay) .

Salaries

Wages

Books and other library materials

Binding

Other expenditures .

Hours per week library was open

$\$ 55,200$

$\$ 34,819$

$\$ 3,262$

$\$ 14,453$

\$ 813

$\$ 1,941$
Total square feet assigned to library . . . . . . 13,084

Stack areas . . . . . 2,500

Seating areas . . . . 6,350

Staff and work areas . . 1,413

Other areas . . . . . 2,300

Expenditures for library per

FTE Student . . . . \$ 19

Expenditures per FTE faculty

member . . . \$ 549

Expenditure ratio of total li-

brary expenditures to total institutional expenditures (excluding capital outlay)

Extrapolation revealed:

Books per FTE Student .

Books per FTE Faculty .

The authors propose that these median benchmarks, updated each year, could possibly form the minimum quantitative threshold standard for adequacy in public junior college libraries throughout the United States. Public junior college libraries falling below these benchmarks, unless special circumstances in their local situation justify a temporary lower level of performance, would be in danger of giving inadequate service to their students and faculty.

As a result of this research, Henry Ford Community College library set as its goal the management data level of the 75th percentile and above. More broadly, it was felt that as a mature public junior college seeking to give good library service to its students and faculty, it would be well advised to use

the threshold figures of the 75th percentile or higher as its objective.

Seventy-Fifth Percentile Benchmarks FOR 1963-64

Number of volumes at the end of year .

Number of volumes added during year .

Number of volumes withdrawn during year .

Number of periodicals being received at end of year. 


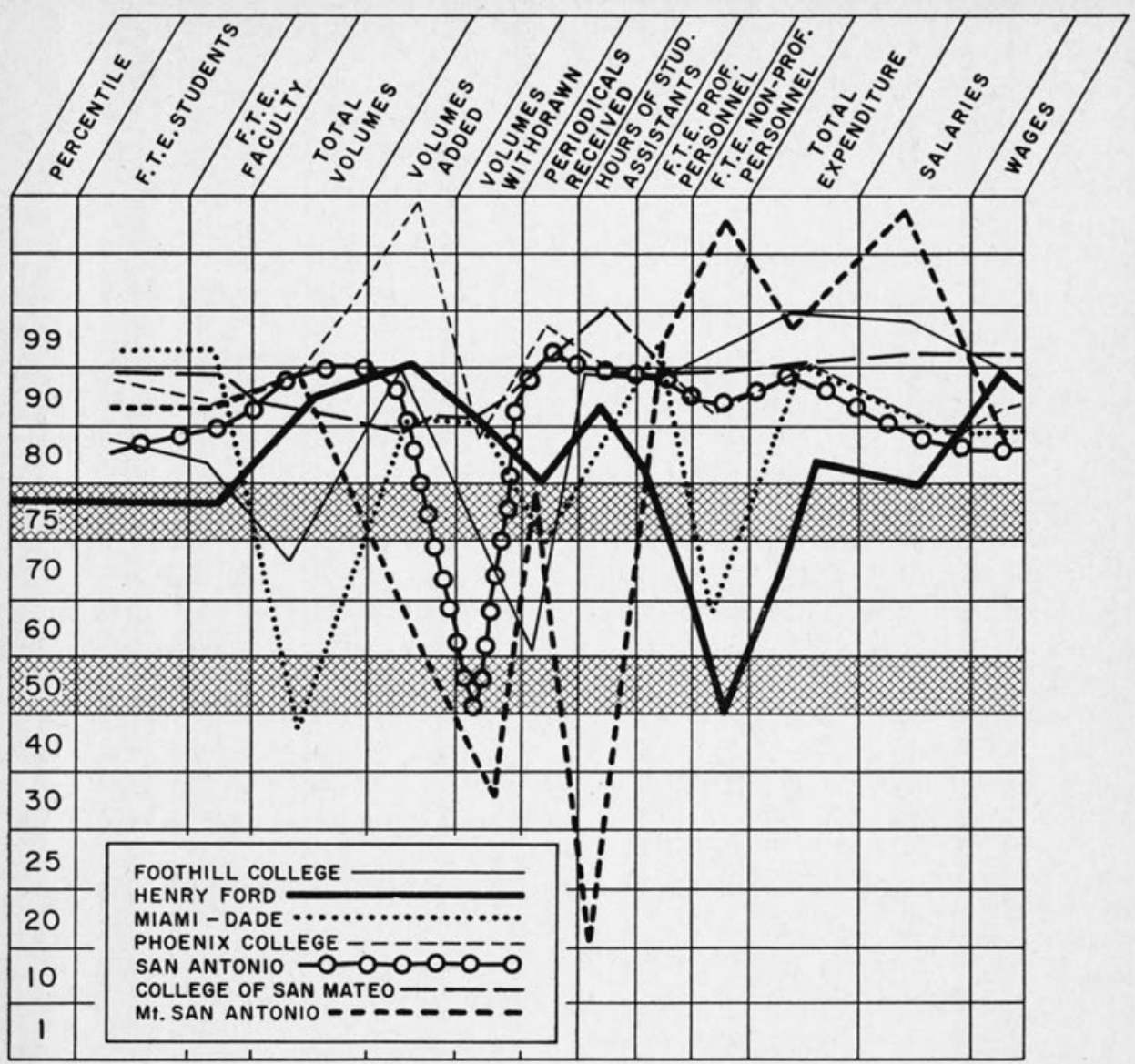

Fig. 1-Selected Management Data on Public Junior College Libraries NoTE: Median and 75th percentile ranking indications are for 86 libraries studied.

Number of hours of student assistance .

Number of professional personnel (FTE) . . . . .

Number of non-professional personnel (FTE) .

Total library expenditures (excluding capital outlay) . Salaries

Wages

Books and other library materials .

Other expenditures

Hours per week library was open

Total square feet assigned to li-

4,197

$\$ 86,087$

$\$ 46,448$

$\$ 5,120$

$\$ 22,472$

$\$ 4,678$

66 brary

20,400

Stack areas . . . . . 4,800

Seating areas . . . . 9,000

Staff and work areas . . 2,320

Other areas . . . . 5,119

Expenditures for library per FTE student

$\$ 26.00$

Expenditures per FTE faculty member .

$\$ 703.00$

Expenditure ratio of total library expenditures to total institutional expenditures (Excluding capital outlay)

Extrapolation revealed: 


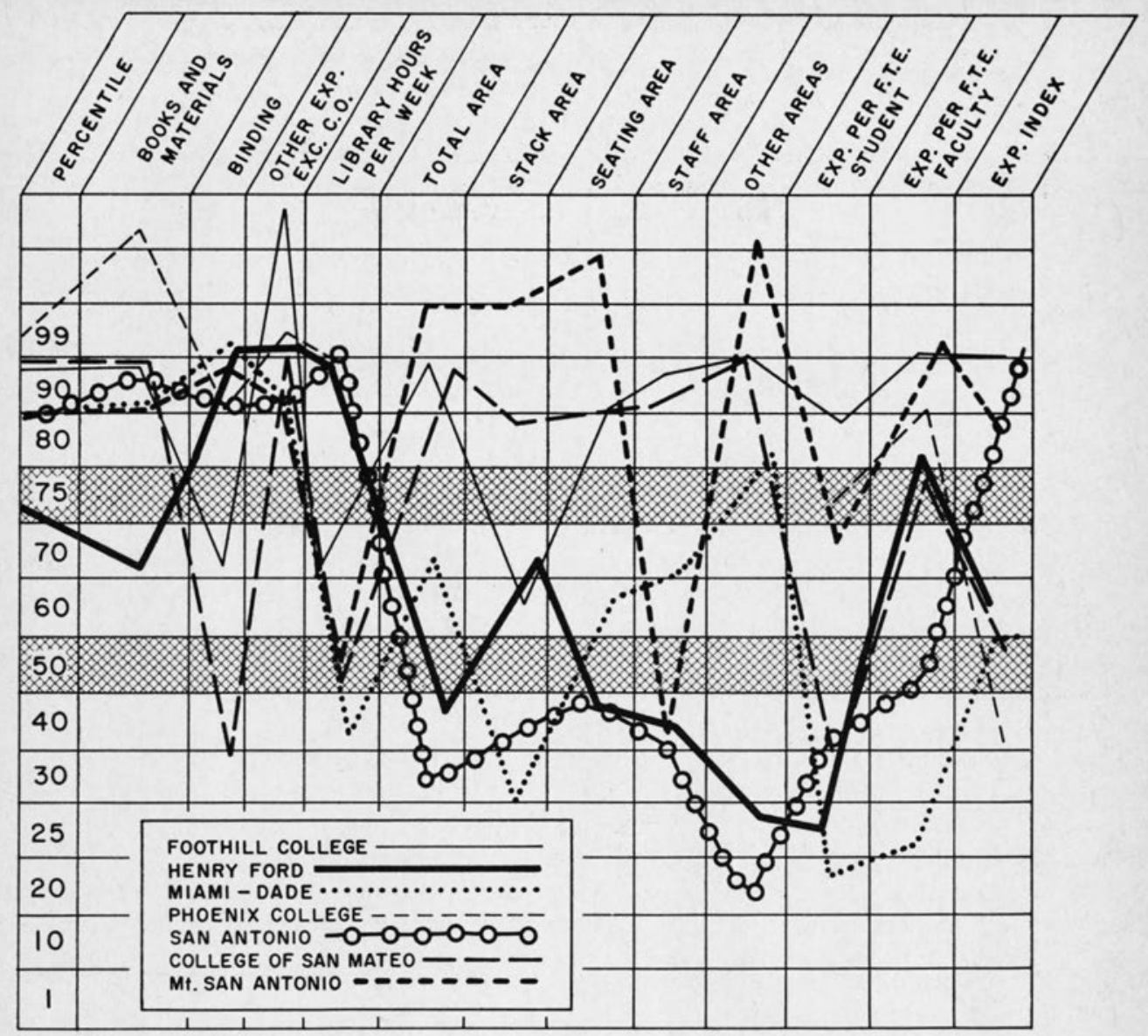

Fig. 1-Selected Management Data (Cont.)

NoTE: Median and 75th percentile ranking indications are for 86 libraries studied.

Books per FTE student . Books per FTE faculty .

\section{Profiles of Practice}

Because the data of all the institutions in this study are ranged on a chart by percentile ranking, it is possible to take the data of any given public junior college library meeting these criteria and graphically portray its profile. This was done with the data of the Henry Ford Community College library, and it was found to indicate a remarkably accurate picture of the practices of the library. Strengths and weaknesses emerged with
7 startling clarity. Lack of adequate cler106 ical personnel, as well as temporary lack of stack and seating space in 1964, were all dramatically evident as the graph line for those items moved far below the 75th percentile line. The large number of gifts from local industry was shown in the peak at "number of volumes added." This graph line, in comparison to the 75th percentile threshold line, presents a significant and useful picture of the management data of the library as we know it.

The authors selected six public junior colleges which had similar enrollments 
and curricula and whose management data, for the most part, fell within the top quartile, that is, above the 75 th percentile. In addition, these six libraries had a national reputation for quality library service, among librarians and educators. These libraries were: Foothill, San Antonio College, Phoenix College, Mount San Antonio College, MiamiDade, and the College of San Mateo. These six libraries and Henry Ford's are portrayed in Figures 1 and 2.

\section{Future Study NeEdED}

In future years, the librarians and administrators at Henry Ford Community College intend to watch developments at these six libraries. In effect, these libraries will become the library standards for Henry Ford.

A possible future task for the authors of this study will be to construct a detailed questionnaire for these six institutions together with Henry Ford, in an attempt to understand them better. An evaluation will be sought as to how the management data are affected by:

1. institutional financing

2. patterns of control

3. curriculum

4. number of fields taught

5. number sections of each course taught

6. number of extension offerings offcampus

7. number of experimental programs

8. number of special institutes held on campus
9. number of institutional research projects in process

10. audio-visual holdings

11. amount of inter-library cooperation

12. educational backgrounds of the professional library personnel

13. number of Ph.D.s on the faculty

14. teaching methods

15. intellectual climate of the campus

16. socio-economic characteristics of the community served

17. educational preparation of incoming students

18. ratio of vocational-terminal to college transfer student

19. honors students

20. record of achievement of graduates

As a final step and only if financial support can be found, the authors may consider visiting these six junior college campuses to survey the libraries and to study each institution in its own setting.

It is doubtful that the benchmarks or the profiles of practice as described in this article can be equated with quality library service. They would appear to indicate, however, a library climate in which quality library service becomes possible. The measurement of quality must await the second and third stages of the study. Meanwhile, if one refrains from making qualitative inferences from the benchmarks and profiles of practice herein outlined, he can use these instruments to find out if a library is on the threshold of having the collection, staff, budget, and other characteristics which are important supporting elements. 